\title{
Institutional and Government Markets: Strategies and Initiatives in the Digital Age
}

Pratap Chandra Mandal, Indian Institute of Management, Shillong, India

\begin{abstract}
Institutional and government markets constitute a not-for-profit market with the main objective of general welfare of people. Such markets are characterized by low budgets and captive patrons. Companies serving institutional markets establish and maintain separate departments to meet the specific requirements. Governments are the major and bulk buyers of goods and services in all countries. Government organizations, appointed by governments, have specified procedures which suppliers should follow. Suppliers experience a number of issues while dealing with government organizations. Suppliers require following formal procedures. The procedures may be time-consuming, and suppliers may face bureaucracy. Governments adopt digital measures and adopt online buying to streamline the processes, to shorten the time required, and to overcome a number of hurdles. Companies dealing with institutional and government markets should be aware of all these aspects to succeed in the long run and also contribute to the growth of institutional and government markets.
\end{abstract}

\section{KEYWORDS}

Government Buyer, Institutional Buyer, Low Budget, Marketing Orientation, Not-for-Profit Market, Online Buying, Welfare

\section{INTRODUCTION}

Institutional and government buyers are the major stakeholders in the market. Institutional and government organizations possess aspects which are similar to business markets and adopt similar strategies for buying as business buyers (Khan, 2016). Although the buying practices are similar, institutional and government organizations form a market which is different from business markets. These organizations possess certain characteristics and needs which are unique and which make them different from business buyers (Kübler \& Lefèvre, 2018). Institutional and government organizations constitute not-for-profit markets. The basic purpose of these organizations is to serve people in their care. The main objective is not to earn revenues and to generate profits like entities in business markets. Although they are not-for-profit organizations, their specific characteristics are important to those entities who conduct businesses with them (Stuart, Larsen, Carvallo, Goldman, \& Gilligan, 2016). Understanding the nature and the characteristics of institutional and government markets and the strategies and initiatives adopted by institutes and governments is important because the size of such markets is large, the revenue generation is substantial, and such markets have diverse stakeholders including the general public. The efficiency and effectiveness of institutional and government markets is linked directly with the welfare of the general public. The welfare of the general public depends to a large extent on the performance of such organizations and markets (Fast, 2018). Analysis of the performance will not be possible unless the markets are studied in-depth. So, it becomes imperative

DOI: 10.4018/IJPADA.20210101.oa7

This article published as an Open Access article distributed under the terms of the Creative Commons Attribution License (http://creativecommons.org/licenses/by/4.0/) which permits unrestricted use, distribution, and production in any medium, provided the author of the original work and original publication source are properly credited. 
to study and analyze institutional and government markets. The study discusses about the various aspects of institutional and government markets. It also focuses on strategies and initiatives taken by institutional and government organizations. Advances in information technology and the widespread usage of the internet allow institutional and government markets to perform their operations faster and better (Winston \& Weinstein, 2016). The roles of the internet in making the buying process for government markets faster, streamlined, and more effective, are highlighted. A study of institutional and government markets and understanding the characteristics of and analysis of the strategies adopted by institutional and government markets are important because these two markets cater to the requirements of a number of buyers.

The above discussions highlight the importance of institutional and government markets. They have specific characteristics and requirements which are unique to such types of markets only. So, these types of markets require a thorough analysis. A conceptual analysis of the literature on institutional and government markets will help analyze and understand such markets better. However, there are few studies which have conducted a conceptual analysis of such markets. The study aims at addressing this research gap.

The objective of the study is to conduct a qualitative and a conceptual analysis of the institutional and government markets and their stakeholders. The study refers to the literature on these types of markets and aims to conduct an in-depth analysis.

The methodology adopted is a qualitative and a conceptual analysis of the literature on institutional and government markets. Latest literature on institutional and government markets was referred to so that the analysis is relevant in the present-day context. The study does not collect primary data on institutional and government markets and does not conduct an empirical analysis.

The novelty and the contributions of the study lie in the fact that a qualitative and a conceptual analysis of the literature might provide deeper insights about institutional and government markets than other types of analyses. The various aspects and issues of institutional and government markets are highlighted. Institutional and government markets will have stakeholders from diverse fields. These different stakeholders will be able to appreciate such issues and the complexities associated with the markets. They will also be able to appreciate the various aspects unique to such markets and the modifications which need to be incorporated in their strategies while serving institutional and government markets. The preparedness will allow the suppliers of such markets to meet the requirements of the markets and serve the markets better.

The study is structured as follows:

Sections 2 discusses about the specific characteristics of institutional markets. Section 3 discusses about the specific characteristics of government markets with sub-sections 3.1 and 3.2 focusing on the necessity of adopting marketing orientation for companies serving government markets and the importance of online buying for government markets respectively. Section 4 discusses about the different strategies adopted and followed for institutional markets while section 5 discusses about the different strategies adopted and followed for government markets. Section 6 discusses the salient points of the study with sub-sections 6.1 and 6.2 focusing on the theoretical implications and the managerial implications of the study respectively. Section 7 concludes the study with sub-sections 7.1 and 7.2 focusing on the limitations of the study and the avenues of future research respectively.

\section{INSTITUTIONAL MARKETS}

Institutional markets consist of organizations which look after the general welfare of people. Such markets include schools, hospitals, nursing homes, prisons, and other institutions that provide goods and services to people in their care (Gomes \& de Abreu, 2019). The main objective of such institutions is not generating profits but the welfare of the individuals under their care. These markets have sponsors which depend on the type of market and on their objectives. Tenet Healthcare operates in business and runs fifty for-profit hospitals in eleven states. The annual revenue generation exceeds 
\$9.2 billion (Terry, Macy, Black, \& Pierce, 2017). However, the Shriners Hospitals for Children is a non-profit organization with 22 hospitals. Free specialized health care for children is provided by the hospitals (Čapek, Culnan, Desai, \& Herndon, 2018). Also, there are government-run Veterans Affairs Medical Centers. Such centers provide special services to veterans and are located across the United States of America (Mielach, 2011). Each institution has different buying needs and preferences.

Prisons in all countries form an institutional market. Prisons provide substantial opportunities because they need to satisfy the requirements of prisoners under their care (Osipian, 2019). The massive and expanding U.S. prisons economy is an example (Resnick, 2011). Around 7.4 million Americans are in prison, on parole, or on probation. The number of prisoners is more than the individual populations of 38 of the 50 states of the United States. The amount of government spending in criminal correction exceeds the budget growth in other sectors like public assistance, transportation, and education. U.S. prisons employ 2.3 million adults and spend about $\$ 74$ billion annually to keep those facilities running (Bluestain, 2012). The United States spend more than $\$ 32000$ per year per prisoner. One analyst comments, "One year in prison costs more than one year at Princeton." Although the prison market is a captive market, it provides enormous opportunities for companies which wish to target the prison market. "Our core business touches so many things - security, medicine, education, food service, maintenance, technology - that it presents a unique opportunity for any number of vendors to do business with us", says one executive at Corrections Corporation of America, the largest private prison operator in the United States (Bluestain, 2012).

Institutional markets have specific and unique characteristics which differ from that of any other market. Such markets are characterized by low budgets and captive patrons (Kübler \& Lefèvre, 2018). For example, hospitals will decide what food will be provided to patients. Patients have little control over the food which is provided to them. The hostel purchasing agent decides the quality of food to be purchased. The buying objective is welfare of people and not generation of profit. Food is provided as part of a total service package. The objective is also not to minimize cost. On the other hand, patients receiving food of poor quality may complain to others. The reputation of a hospital may get damaged if food of poor quality is served. Patients may fall sick due to the poor quality of food and the reputation of hospitals may get damaged. Thus, the hospital purchasing agent must search for institutional food vendors whose quality meets or exceeds a certain minimum standard and whose prices are low (Mielach, 2011). However, hospitals accept inferior quality to save on costs.

Institutional buyers have different requirements which are met by the different departments maintained by companies (Crawford-Garrett \& Clare Mbizule, 2016). For example, the General Mills Foods service unit produces, packages, prices, and markets its broad assortment of cereals, cookies, snacks, and other products. The institutions which these products serve include hospitals, hotels, schools, and other institutional markets (Mielach, 2011). The Procter \& Gamble Professional Division provides special services for professional cleaning and laundry formulations and systems to educational, health care, and other institutional and commercial customers (Mielach, 2011).

\section{GOVERNMENT MARKETS}

Government markets include those institutions and companies which are appointed by a government to function on its behalf or those institutions which perform the main functions of government. Such government units may include federal, state, local purchase, or rent goods and services (Mah, 2020). Government markets offer excellent opportunities for both large and small companies. Governments of all countries are the major and bulk buyers of foods and services. Companies serving government markets generate substantial revenues. In the United States alone, federal, state, and local governments contain more than 88000 buying units that purchase more than $\$ 1$ trillion in goods and services each year (Gormley, 2009). Buying in business markets and buying in government markets have several characteristics in common. There are differences too. Companies selling to governments should understand the differences which will help them to become better suppliers. The companies should 
understand the various stages and requirements in buying for governments. They must locate key decision makers, identify the factors that affect buyer behavior, and understand the buying decision process (Chen, 2020).

Governments have their own criteria and preferences for selecting suppliers. Although formal procedures are followed for government buying, it is not as rational as it is made out to be (Chen, 2018). Governments tend to favor domestic suppliers to foreign suppliers more, even sometimes at the cost of low quality (Gormley, 2009). A major complaint of multinationals operating in Europe is that each country shows favoritism towards its national suppliers even when the foreign firms might have made superior offers. The European Economic Commission aims to gradually reduce this bias (Canaday, 2008).

Government buyers, like consumer and business buyers, require to be aware about the business environment (Mah, 2020). Government buyers, like consumer and business buyers, are also affected by environmental, organizational, interpersonal, and individual factors. They require competing with all these forces in the external environment. Government buying is being scrutinized by all stakeholders closely. The money of taxpayers is involved in government spending. Outside publics ranging from the Congress to a variety of other private groups are interested in knowing how the government spends taxpayers' money. Government organizations require maintaining documents from suppliers. Government organizations themselves do documentation of all transactions. Suppliers require maintaining all documents regarding transactions. They often complain about excessive paperwork, bureaucracy, regulations, decision-making delays, and frequent shifts in procurement personnel (Gormley, 2009).

Companies doing business with government organizations face a number of issues. However, even after knowing that there will be hurdles, companies prefer doing business with governments. There are several reasons for doing business with governments. Most of the governments are major and bulk buyers of a number of products and services. For example, the U.S. government is the world's largest buyer of products and services. U.S. government buying amounts to more than \$461 billion each year. Also, U.S. government is prompt in paying to the companies (Chi, 2019). U.S. government buys a range of products from socks to stealth bombers. In 2014, the federal government spent $\$ 80.9$ billion on information technology, $\$ 20$ billion of which was spent for transitioning to cloud computing systems (Chi, 2019). Companies dealing with governments are able to sell in bulk and are able to generate substantial amount of revenues. So, it is beneficial for companies to build and develop long-term relationships with governments.

Many governments provide potential buyers with detailed guides of the process of selling to the governments (Kamble \& Walvekar, 2020). Buyers are able to know and become acquainted with the requirements of the processes. The U.S. Small Business Administration provides on its website detailed advice for small businesses seeking government contracting opportunities (www.sba.gov/ federal-contracting/contracting-guide). Information and advice on international trade opportunities are available on the U.S. Commerce Department's website (www.commerce.gov/work-with-us/ grants-and-contract-opportunities) (Friesen \& Eddy, 2019).

General Services Administration operates in several major cities of the United States. Several Business Service Centers operate under General Services Administration. The centers provide information on how government agencies buy, the steps that suppliers should follow, and the procurement opportunities available. Important information about various institutions like highway departments, hospitals, schools, and other government agencies are available in trade magazines. Websites are maintained by all government organizations and associations. The websites provide updated information and service (Gavazza, Nardotto, \& Valletti, 2019). Such websites become quick and authentic sources of information for suppliers.

Suppliers should be conversant with and should understand the system well. They should also know how to deal with large government purchases (Kamble \& Walvekar, 2020). There are several companies which deal only in contracts with the government. For example, Envisage Technologies 
is a small software development company that specializes in internet-based training applications and human resource management issues (Gormley, 2009). The company has more than 65 percent of its contracts with the federal government. Envisage gains access to smaller procurements with the help of the information available on the website of the General Services Administration. Envisage is efficient and prompt and receives responses within 14 days. Envisage focuses on large and highly coveted contracts because such contracts are the most lucrative ones. A comprehensive bid proposal prepared by Envisage for any of these contracts is in-depth and can easily run from 600 to 700 pages because of federal paperwork requirements (Canaday, 2008). Envisage prepares single bid proposal carefully and meticulously. It spent as many as 5000 labor-hours over the course of a few years (Canaday, 2008).

Streamlined procedures and policies are followed for government buying. So, people believe that government buying is rational. However, government buying is not as rational as it is made out to be. Government buying follows different procedures and criteria. Different non-economic criteria also play a major role in government buying (Neto, 2020). Different individuals serving in governments have their own selfish motives to fulfill. Government buyers have to satisfy the interests of a number of stakeholders and may need to favor loss-making business firms and areas, small business firms, minority-owned firms, and business firms that avoid gender, age, and race discrimination (Swibel and Novack, 2003). Sellers should keep these factors in mind when they consider serving government businesses.

\subsection{Marketing Orientation for Companies Serving Government Markets}

All companies which sell to governments may not always have a marketing orientation (Sahedi, 2012). There are several reasons. One of the main reasons is that total government spending is determined by the elected government officials who do not put any effort to develop the market. Governments supply in bulk quantities, focus on saving costs, and look for the lowest prices. Consequently, suppliers require bringing down their costs to fulfill the requirements of governments. To reduce costs, suppliers invest in technology, make their processes faster and streamlined, and generate long-term revenues (Sahedi, 2012). Governments are particular about their needs and product specifications. Product differentiation is not of prime importance in government buying. Consequently, advertising or personal selling may not matter much in winning bids on an open-bid basis (Gromley, 2009).

Companies establish separate marketing departments to serve governments. Such companies include Boeing, General Electric, and Goodyear. Other companies sell primarily to government buyers, such as Lockheed Martin which makes 84 percent of its sales from the U.S. government. The company acts either as a prime contractor or as a sub-contractor (Warren, 2010). The main jobs of these companies include anticipating government needs and projects, participating in the product specification phase, gathering competitive intelligence, preparing bids carefully, and producing stronger communications to describe and enhance the reputation of their companies.

Companies have separate and customized marketing programs for government buyers. For example, Dell maintains separate business units to understand and satisfy the requirements of federal, state, and local government buyers. Apart from providing services to its regular customers, Dell offers customized services for government buyers on its official website, Dell.com. The services include special pricing, online purchasing, and service and support for each city, state, and federal government entity (Woyke, 2011).

\subsection{Online Buying for Government Markets}

Online buying is gaining importance in government buying. Governments realize the potential and the necessity of online buying for making the buying process streamlined, fast, and convenient. The Federal Business Opportunities website (FedBizOpps.com at www.fbo.gov) provides a single point of entry where commercial vendors and government buyers can post, search, monitor, and retrieve opportunities solicited by the entire federal contracting community (Sahedi, 2012). Several federal agencies are available and they do purchase on behalf of the government. Such agencies maintain 
official websites where governments can perform online buying (Warren, 2010). These include the General Services Administration (GSA), the Department of Veteran Affairs, and the Defense Logistics Agency. The U.S. government buys more than one quarter of its requirements from the General Services Administration. It operates a GSA Advantage! Website (www.gsaadvantage.gov). The Defense Logistics Agency offers an Internet Bid Board System (www.dla.mil) for purchases by America's military services. E-procurement can be done from the Department of Veterans Affairs through its VA Advantage! website (https://VAadvantage.gsa,gov) (Warren, 2010).

The websites mentioned allow authorized defense and civilian agencies to procure office supplies, food, information technology equipment, and construction services through online purchasing. All the websites maintained by the General Services Administration, the Defense Logistics Agency, and the Department of Veterans Affairs sell merchandize to the authorized individuals. The websites also facilitate in establishing direct links between government buyers and contract suppliers (Gavazza, Nardotto, \& Valletti, 2019). For example, a branch of the Defense Logistics Agency sells medical supplies to military forces. The branch places orders directly to vendors such as Bristol-Myers Squibb (Gormley, 2009). Several hassles and delays which act as obstacles in government purchasing get automatically eliminated because of online purchasing (Gavazza, Nardotto, \& Valletti, 2019).

\section{MARKETING STRATEGIES FOR INSTITUTIONAL MARKETS}

Companies operating in institutional markets need to serve the requirements of diverse stakeholders and adopt a number of marketing strategies to meet the requirements of their stakeholders. Companies serving different institutional markets adopt different strategies. Companies involved in food business set up a separate sales division to cater to the requirements of institutional buyers (Bredahl, 2019). Heinz processes its ketchup differently to satisfy the requirements of and to deliver to hospitals, prisons, and colleges. The ketchup is produced, packaged, and priced differently (Larkin, 2020).

Different companies operating in institutional markets adopt different marketing strategies. ARAMARK is a company which adopts different strategies to serve different institutional markets. ARAMARK delivers food services for stadiums, arenas, campuses, businesses, and schools (King, 2003). ARAMARK has a competitive advantage in delivering food to the prisons of the United States. ARAMARK refined its purchasing practices and supply chain management to gain this competitive advantage. Previously, potential suppliers provided the lists and ARAMARK used to select products from the lists. At present, ARAMARK realizes that different institutional markets have their own specific requirements. ARAMARK needs to customize its products to meet the requirements (Swibel \& Novack, 2003). Previously, quality was compromised to meet food cost limits. Such low prices cannot be matched by operators outside the market. John Zillmer, president of ARAMARK's Food and Support Services, comments, "When you go after business in the corrections field, you are making bids that are measured in hundredths of a cent. So, any edge we can gain on the purchasing side is extremely valuable.” To satisfy the specific requirements for a series of protein products, ARAMARK searched for unique partners who could satisfy those requirements. The partners provided the products at price points which ARAMARK never could have imagined before (King, 2003). The partners had in-depth knowledge about protein products. They knew how to provide low-priced products without compromising with the chemistry of proteins and the quality of the products. Such initiatives allowed ARAMARK to lower its costs. ARAMARK replicated the process with 163 different items formulated exclusively for corrections (Swibel \& Novack, 2003). This also enabled ARAMARK to reduce the price of meals by five to nine cents instead of one cent it used to reduce previously. All these were achieved while maintaining or improving the quality (King, 2003). 


\section{MARKETING STRATEGIES FOR GOVERNMENT MARKETS}

Companies operating in government markers adopt a number of marketing strategies to meet the requirements of their stakeholders. Governments are the major buyers of goods and services in all countries. Governments require suppliers to adhere to different guidelines and policies formulated by the governments. Suppliers interested in selling to governments are required to submit bids. Governments evaluate the bids based on a number of criteria and often award the contract to the lowest bidder. However, at the same time, governments do not compromise with quality. Contracts are awarded to those suppliers who provide superior quality and who have the reputation of completing large projects on time (Sauda \& Ngeny, 2019). Governments also buy on a negotiated contract basis, primarily in complex projects with major research and development costs and risks and those where there is little competition (Gromley, 2009).

Favoritism might be an issue in government markets. Multinational companies in Europe display favoritism in selecting suppliers. Each country in Europe chooses suppliers from its nationals even when superior quality is offered by foreign suppliers (Burrows, 2010). Various agencies and unions aim to curb such practices in recent times. The European Union takes various initiatives to remove the bias. Economic cycles and swings generate fluctuations in spending and this is a major challenge. When state governments suddenly cut back their spending, a firm like Cisco is likely to feel the effects because Cisco generates 22 percent of its sales by supplying to the public sector (Burrows, 2010). In 2011, the U.S. government announced a long-term cut back of hundreds of billions of dollars in defense spending. Such cuts which are anticipated in future also will affect the sales of many defense contractors (Sahedi, 2012).

The general public reviews the spending decisions of government and government organizations (Furton \& Martin, 2019). Considerable paperwork by suppliers is required to facilitate the review process. Suppliers complain about bureaucracy, regulations, decision-making delays, and frequent shift in procurement staff. Nevertheless, a substantial portion of the federal budget of the United States (roughly 14 percent) is spent on private-sector contractors. Because of such spending, the U.S government is the largest and potentially the most attractive customer in the world (Woyke, 2011). Motorola Solutions which was created when Motorola was split into two companies, sells wireless communications equipment to public safety agencies around the world. These agencies require state-of-the-art communications networks for police cars in a multibillion-dollar government market (Woyke, 2011).

The number of individual purchases and the amount of revenue generated from such purchases are quite high. According to the General Services Administration Procurement Data Center, more than 20 million individual contract actions are processed every year (Sahedi, 2012). The prices of the items range between $\$ 2500$ and $\$ 25000$. In addition to these, government purchases in billions, mainly in technology (Sahedi, 2012).

Governments maintain proper relationships with their suppliers. However, governments may have a number of grievances against suppliers. A main complaint against the suppliers is that they do not do proper homework. The government has varied customers - defense, civilian, and intelligence - and each of them have their own specific requirements. They have different needs, priorities, purchasing styles, and time constraints. Suppliers should acknowledge the specific requirements of each of the stakeholders and modify their supplies based on the requirements of stakeholders. Although product quality is important, one of the main concerns for government procurement professionals is cost minimization which is often not followed by suppliers (Cohen \& Li, 2020). Companies who desire to be government contractors should help government agencies and should try to analyze the bottom-line impact of products. Suppliers should convince governments by communicating previous experiences and successful past performance. Suppliers may convince governments by presenting case studies of their superior past performance with other government organizations. 
Companies provide government agencies with detailed procedures and guidelines for purchasing products. Similarly, suppliers are also provided with detailed procedures and guidelines specifying the process of selling to governments. Suppliers may get their contracts terminated and may have to face legal actions if they fail to abide by the procedures and guidelines (Sauda \& Ngeny, 2019).

The federal government specifies the procedures and guidelines to streamline the buying process from suppliers. It focuses on simplifying the contracting procedure and making bidding more attractive. Buying off-the-shelf items is given higher importance than customization. The process is made faster and convenient by communicating with vendors online. This also eliminates substantial amount of paperwork. The government debriefs losing vendors to improve their chances of winning in future (Sahedi, 2012). Online purchasing via web-based forms, digital signatures, and electronic procurement cards (P-cards) is given more importance (Hayu, Surachman, Rofiq, \& Rahayu, 2020).

It is difficult for governments to make purchases themselves. The government appoints federal agencies to act as purchasing agents on its behalf. Federal agencies maintain their own websites where authorized defense and civilian agencies can buy everything from medical and office supplies to clothing through the catalogs maintained on the websites (Warren, 2010). Stocked merchandize may be procured from the website of the General Services Administration. Such websites facilitate in creating and in maintaining direct contacts between buyers and contract suppliers. The U.S. government requires that any company willing to do business with the government should ensure that the company is listed in the Central Contractor Registration (CCR) database (www.ccr.gov). The database collects, validates, stores, and disseminates data in support of agency acquisitions (Sahedi, 2012). Maintenance of databases helps in streamlining the entire process.

Marketing orientation is missing among many of the companies doing business with governments (Esakki, 2017). However, different departments of governments have different requirements and companies require knowledge of marketing to understand those requirements well. Some of the companies realize the importance of marketing and develop separate marketing departments which cater to the requirements of government. Companies like Goodyear, Rockwell, Gateway, and Kodak anticipate government needs and projects, participate in the product specification phase, gather competitive intelligence, prepare bids carefully, and produce strong communications to describe and enhance their companies' reputations (Sahedi, 2012).

\section{DISCUSSIONS}

The institutional market consists of organizations and institutions which include hospitals, schools, nursing homes, prisons, and other institutions that provide goods and services for the welfare of people. Government markets include government organizations that have bureaucracy which forces buyers to undergo a great deal of paperwork from their vendors. Government organizations favor open bids and tend to give preference to domestic companies over foreign companies. Institutional and government markets have specific characteristics which are unique and requirements which differ from that of other markets. Suppliers should be able to adapt to those specific characteristics, requirements, and procedures. Government markets are characterized by low budgets and captive patrons. The government market is vast and consists of government units - federal, state, and local.

Government buying is complicated and involves a number of steps. It is difficult for governments to make purchases themselves. The government appoints units and agencies which purchase or rent goods and services for carrying out the main functions of government. Government buyers purchase products and services for defense, education, public welfare, and other public needs. Government buying has highly specialized and specified requirements. The process includes open bidding and negotiated contracts. In the United States, the Congress and many private watchdog groups monitor the activities of government buyers. Consequently, they tend to be more formal and require many forms and signatures. They also respond more slowly and deliberately when placing orders. Government 
markets are adopting online buying in the digital age to make the processes faster, streamlined, and convenient.

The study focused on discussing institutional markets, their requirements, and characteristics. The study also discussed about government markets, their requirements, and characteristics. Companies serving government markets require maintaining a marketing orientation to cater to the different requirements of different departments of governments. Government markets also encourage and practice online buying to make the processes streamlined, fast, and convenient. Finally, the study focuses on the different strategies and initiatives adopted by companies serving institutional markets and government markets.

\subsection{Theoretical Implications}

Academicians will be able to understand the specific characteristics of institutional and governments. They will be able to appreciate the specific requirements of such markets. They will also be able to realize how the customer requirements in such markets are different from that in other types of markets. They will be able to understand the importance of institutional and government markets in the generation of revenues of companies serving such markets. Based on the discussions done in the study, they might suggest a conceptual framework to analyze institutional and government markets. The framework might be used by governments and authorities formulating guidelines for institutional and government markets. They will also be able to appreciate the necessity of developing long-term relationships between companies and institutional and government markets to create a win-win situation.

\subsection{Managerial Implications}

Practicing managers will understand the current trends and developments in institutional and government buying and delve deeper into analyzing the changing requirements and suggest strategies and initiatives accordingly. They will understand the specific characteristics of institutional and government markets. They will understand the importance of having a marketing orientation for serving institutional and government markets and online buying to make the processes faster, streamlined, and convenient. They will be able to formulate strategies and initiatives to meet the specific requirements. This will help in developing better bonding and relationships between suppliers and institutional and government organizations and result in a win-win situation for all the concerned stakeholders.

\section{CONCLUSIONS}

The study discussed about the different and the specific characteristics of institutional and government markets. Such markets adopt a number of strategies and initiatives to attract vendors. Institutional markets provide goods and services to people in their care. Different institutions have different characteristics and requirements. General welfare of people, rather than revenue and profit generation, is the main objective of such institutions. Such markets are characterized by low budgets and captive patrons.

Governments are the major and bulk buyers in most countries. Government organizations follow specific procedures which suppliers require to abide by while delivering goods and services. Suppliers are required to submit bids. Normally the supplier who offers the lowest price gets the contract. However, quality is not compromised for low price. The process is more formal and may pose hurdles for suppliers. Domestic suppliers seem to be preferred more than foreign suppliers. Like consumer and business buyers, government organizations also require to be aware about the business environment. Marketing departments are established by companies to cater to the specific business requirements of government organizations. Government organizations are shifting towards e-procurement and online transactions to make the buying process faster and streamlined. The discussions will help in 
developing proper understanding between institutional and government markets and their suppliers. This in turn will result in streamlining the processes and the delivery of products and services.

\subsection{Limitations}

The study focused on conducting a qualitative and a conceptual analysis of the literature on institutional and government markets. The study did not collect primary data and conduct an empirical analysis. Also, although the study discussed a number of aspects regarding doing businesses in institutional and government markets, it focused mainly on the institutional and government markets in the United States.

\subsection{Avenues of Future Research}

Researchers may collect primary data about the various aspects of institutional and government markets and may conduct an empirical analysis. Based on the insights obtained from such analysis, companies serving institutional and government markets may adopt initiatives which are actionable. Based on the discussions done in the context of the United States, researchers may analyze whether the strategies and the initiatives may be extended to institutional and government markets of other countries. They may also analyze the characteristics and the different requirements of institutional and government markets of other countries and suggest developing effective strategies and initiatives accordingly.

The discussions may help academicians to understand the specific characteristics and requirements of institutional and government markets and organizations. Both institutional and government markets are entering into the digital age where the internet facilitates the buying and the selling processes in the form of e-procurement. They may study and analyze the marketing strategies followed by these organizations and ascertain their effectiveness. Researchers may analyze and evaluate the roles of the internet in the process. They may also suggest how effectively the strength of the internet may be utilized in future. Researchers may suggest conceptual frameworks which will help to study and analyze institutional and government markets better. Efforts were made to include the latest and the relevant literature for understanding institutional and government markets. Based on the analysis, strategies may be suggested that will be more effective. The discussions will sensitize the researchers to understand the processes for institutional and government markets. 


\section{REFERENCES}

Bredahl, M. E. (2019). Competitiveness in International Food Markets. CRC Press. doi:10.1201/9780429037597

Burrows, P. (2010, November 22). Investors Fret as Cisco Scales Back Forecasts. Bloomberg Businessweek, 49-50.

Canaday, H. (2008, June). Government Contracts. Selling Power, 59-62.

Čapek, K. D., Culnan, D. M., Desai, M. H., \& Herndon, D. N. (2018). 50 Years of Burn Care at Shriners Hospitals for Children, Galveston. Annals of Plastic Surgery, 80(3, Suppl 2), S90-S94. doi:10.1097/SAP.0000000000001376 PMID:29461291

Chen, Y. (2018). Study on the Risk Evaluation of Government Purchasing Public Service Based on Matter Element Extension Model. Open Journal of Social Sciences, 6(02), 127-143. doi:10.4236/jss.2018.62012

Chen, Y. (2020). The Dual Attributes of Government. In New Economic Engine: Effective Government and Efficient Market (pp. 33-44). Springer. doi:10.1007/978-981-15-2922-1_4

Chi, F. (2019). Promoting Government Reform with a Focus on Regulatory Changes. In Winning at the Turning Point (pp. 329-377). Palgrave Macmillan. doi:10.1007/978-981-32-9479-0_8

Cohen, D. A., \& Li, B. (2020). Customer-Base Concentration, Investment, and Profitability: The US Government as a Major Customer. The Accounting Review, 95(1), 101-131. doi:10.2308/accr-52490

Crawford-Garrett, B., \& Clare Mbizule, K. (2016). International-The Rise of Institutional Food Procurement: A Tool for Empowering Women or Furthering the Status Quo? In Women in Agriculture Worldwide (pp. 203220). Routledge.

Esakki, T. (Ed.). (2017). Green Marketing and Environmental Responsibility in Modern Corporations. IGI Global. doi:10.4018/978-1-5225-2331-4

Fast, A. (2018). Chinese Regional Development, a Consequence of State Interventions or the Private Sector? Degree Project-Master's Programme. Lund University.

Friesen, M., \& Eddy, M. (2019). Selling the Service: Veterans' Reflections on their Past Experience of the Military Recruitment Process. Critical Military Studies, 5(3), 213-237. doi:10.1080/23337486.2018.1537648

Furton, G., \& Martin, A. (2019). Beyond Market Failure and Government Failure. Public Choice, 178(1-2), 197-216. doi:10.1007/s11127-018-0623-4

Gavazza, A., Nardotto, M., \& Valletti, T. (2019). Internet and Politics: Evidence from UK Local Elections and Local Government Policies. The Review of Economic Studies, 86(5), 2092-2135. doi:10.1093/restud/rdy028

Gomes, T. T., \& de Abreu, L. S. (2019). Perceptions of Family Farmers and Technicians in the Ribeira Valley Region about the Institutional Market. Extensão Rural, 26(4), 51-68. doi:10.5902/2318179630773

Gormley, B. (2009, January 23). The U.S. Government Can Be Your Lifelong Customer. Washington Business Journal.

Hayu, R., Surachman, S., Rofiq, A., \& Rahayu, M. (2020). The Effect of Website Quality and Government Regulations on Online Impulse Buying Behavior. Management Science Letters, 10(5), 961-968. doi:10.5267/j. msl.2019.11.015

Kamble, A. A., \& Walvekar, S. (2020). Policy Regulations in E-Commerce Sector-Critical Analysis of FDI Guidelines for Market Place Model. Journal of Commerce and Management Thought, 11(1), 71-79.

Khan, H. R. (2016). Public Debt Management: Reflections on Strategy and Structure. In Public Debt Management (pp. 9-22). Springer. doi:10.1007/978-81-322-3649-8_2

King, P. (2003, August 18). Purchasing: Keener Competition Requires Thinking Outside the Box. Nation's Restaurant News, 87.

Kübler, D., \& Lefèvre, C. (2018). Megacity Governance and the State. Urban Research \& Practice, 11(4), 378-395. doi:10.1080/17535069.2017.1347810 
Larkin, M. B. (2020). Board Gender Diversity, Corporate Reputation and Market Performance. International Journal of Banking and Finance, 9(1), 1-26.

Mah, D. N. Y. (2020). Conceptualising Government-Market Dynamics in Socio-Technical Energy Transitions: A Comparative Case Study of Smart Grid Developments in China and Japan. Geoforum, 108, 148-168. doi:10.1016/j.geoforum.2019.07.025

Mielach, D. (2011, December 27). Small Businesses Spend More to Do Business with the Government. BusinessNewsDaily.

Neto, B. (2020). Analysis of Sustainability Criteria from European Public Procurement Schemes for Foodservices. The Science of the Total Environment, 704, 135300. doi:10.1016/j.scitotenv.2019.135300 PMID:31836237

Osipian, A. L. (2019). The Invisible Hand of the Market and Invincible Hand of the Raider. In Political and Economic Transition in Russia (pp. 131-152). Palgrave Macmillan. doi:10.1007/978-3-030-03831-1_7

Resnick, B. (2011, November 1). Chart: One Year of Prison Costs More Than One Year at Princeton. Atlantic (Boston, Mass.).

Sahedi, J. (2012, July 23). Cutting Washington Could Hit Main Street. www.money.cnn.com

Sauda, Z. A., \& Ngeny, G. K. (2019). Effect of Supplier Evaluation on Performance of Procurement Contract: A Case Study of Coast Provincial General Hospital. The Strategic Journal of Business \& Change Management, 6(2), 244-264.

Stuart, E., Larsen, P. H., Carvallo, J. P., Goldman, C. A., \& Gilligan, D. (2016). US energy service company (ESCO) industry: Recent market trends. Academic Press.

Swibel, M., \& Novack, J. (2003, November 10). The Scariest Customer. Forbes, 96-97.

Terry, N., Macy, A., Black, A., \& Pierce, M. (2017). The Affordable Care Act Impact on Stock Performance of Hospital Service Companies. Southwestern Economic Review, 44, 59-73.

Warren, C. (2010, February 6). How to Sell to Uncle Sam. BNET Crash Course.

Winston, W., \& Weinstein, A. (2016). Defining Your Market: Winning Strategies for High-Tech, Industrial, And Service Firms. Routledge. doi:10.4324/9781315865461

Woyke, E. (2011, November 7). The Other Motorola. Forbes, 52-54.

Pratap Chandra Mandal is an Assistant Professor (Marketing) at Indian Institute of Management, Shillong, India. He has completed graduate degree from the reputed Indian Institute of Technology, Kharagpur (IIT Kharagpur), India (Bachelor of Technology in Mechanical Engineering), post-graduate degree from Vinod Gupta School of Management, IIT Kharagpur (Masters in Business Administration), PhD (Marketing) from Vinod Gupta School of Management, IIT Kharagpur. His research concerns customer relationship management, customer satisfaction, services marketing, marketing intelligence, and qualitative methods in management. He is the editor-in-chief of two international journals and is on the editorial board of journals like Journal of Global Marketing. Pratap has won several prestigious scholarships and awards throughout his academic career. 